International Journal of Instruction e-ISSN: 1308-1470 • www.e-iji.net

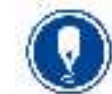

January $2021 \bullet$ Vol.14, No.1

p-ISSN: 1694-609X

pp. $215-234$

Article submission code:

20191222044230

Received: 22/12/2019

Revision: 14/06/2020
Accepted: 04/07/2020

OnlineFirst:11/10/2020

\title{
Teacher's Use of Literacy Centers to Promote Literacy Acquisition in First Grade Bilingual Students in a South Texas School
}

\section{Fernando Hernandez}

Asst. Prof., Texas A\&M University- Kingsville, USA, fernando.hernandez@tamuk.edu

$\mid$

Improving reading performance among Hispanic students continues to be a national and state priority. The purpose of this study was to investigate the effectiveness of literacy centers in first grade bilingual classrooms and its relation to students' Tejas LEE scores. This quasi-experimental study took place in two elementary schools in a South Texas district during an 11-week period. Data were collected through BOY (Beginning of the year) and MOY (Middle of the year) Tejas LEE scores. A nonprobability sample consisted of 104 first grade bilingual students (59 and 45 in the experimental and comparison groups, respectively). Results showed that there was no statistically significant difference between those students who participated in literacy centers and those who did not based on the Tejas LEE scores. Given the growing number of Hispanics and recognizing the reading gap, it is important to find a solution to this problem. This study is a start in reducing the number of first grade students being retained due to their literacy ability.

Keywords: literacy centers, economically disadvantaged students, bilingual students, literacy development, literacy acquisition

\section{INTRODUCTION}

In primary education, there is an emphasis on No Child Left Behind and closing the academic gap in student's performance. One answer to these issues lies in establishing a strong literacy foundation through strategies such as the use of literacy centers. Researchers and early childhood educators have recognized the importance of play in children's learning and development (Fromberg, 2002; Singer, Golinkuff, \& HirshPasek, 2006). It has been found that children acquire literacy skills when they are involved in literacy interactions in play environments. Play allows children to participate in reading and writing experiences that develop the literacy skills necessary for formal reading instruction (Saracho \& Spodek, 2006). However, most of the research published has focused only on the early grades such as pre-kindergarten and kinder and not on grades higher than $1^{\text {st }}$ grade. The transition that students experience in kindergarten is different from first grade. In kindergarten, students are engaged in different literacy centers to promote literacy development and socialization skills. They work with blocks, experiment with the sand and water table, play in the dramatic area

Citation: Hernandez, F. (2021). Teacher's Use of Literacy Centers to Promote Literacy Acquisition in First Grade Bilingual Students in a South Texas School. International Journal of Instruction, 14(1), 215-234. https://doi.org/10.29333/iji.2021.14113a 
and participate in games and songs. When students advance to first-grade, they are bombarded with skills in preparation for assessments administered daily or weekly, leaving little time for play. In fact, play is viewed as a waste of time and is rapidly disappearing (Miller \& Almon, 2009). First grade students need the opportunity to engage in different types of play to acquire the necessary knowledge to be successful readers and writers (Tyre, 2006).

Improving the reading performance of Hispanic students continues to be a national and state priority. The Nation's Report Card is an ongoing assessment of what U.S. student know and can do in different subjects. According to the National Assessment of Educational Progress (NAEP) 2015 reading results, Hispanic students performed lower than other students in $4^{\text {th }}$ grade. Hispanics obtained an average score of $208(21 \%)$, while Whites scored a $232(46 \%)$, resulting in a 25 point gap in average score. Students eligible for National School Lunch Program (NSLP) obtained an average score of 209, while English Language Learners received an average score of 189. Furthermore, in the state of Texas, $4^{\text {th }}$ grade Hispanic students obtained an average score of 210 compared to White students who received an average score of 235 , scoring 25 points higher than did Hispanic students (NAEP, 2015). In the spring of 2015, results of the $3^{\text {rd }}$ Grade Reading Spanish STAAR (State of Texas Assessments of Academic Readiness) test showed 12,671 (35\%) students received a level I score, meaning that reading skills were not mastered (Texas Education Agency, 2016).

The need to improve reading ability in first grade to avoid retention, especially for Hispanic students is of great concern in Texas. In the 2013-2014 school year, first grade students in Texas had a higher retention rate of $4.6 \%$ (18,378 students) than any other elementary grade. Hispanic first grade students had a retention rate of 5.3\% (11,547 students). Students identified as economically disadvantaged had a retention rate of $5.9 \%$ (15,596 students), compared to non-economically disadvantaged students, who had a $2.1 \%$ retention rate (2,737 students) (Texas Education Agency, 2015). According to Kenneady (2004), retention is strongly associated with dropping out of school in later years. A retained student is $50 \%$ more likely to drop out of school than a non-retained student; two retentions increase that probability to $90 \%$. According to the Annie E. Casey Foundation study, 33\% of Hispanic students who had poor reading skills and were economically disadvantaged, did not finish school (Hernandez, 2012). Furthermore, poor reading skills are connected to unfavorable life outcomes. Northwestern University study revealed that young male high school dropouts were 47 times more likely to be incarcerated than their similarly aged peers who held a four year college degree (Sum, Khatiwada, McLaughlin, \& Palma, 2009).

The use of literacy centers with bilingual students has been largely unexplored. Information on literacy centers exists mainly in how-to books and a few dissertations, and even fewer studies done specifically with bilingual prekindergarten students. This study contributed to the literature by attempting to fill this void in research by examining the possibilities of fostering literacy acquisition through the implementation of literacy centers with economically disadvantaged Hispanic students, living in "colonias," who are considered "at-risk" of dropping out of school. 
In Texas, there are people living in colonias of extremely low-income communities along the Texas-Mexican border. Compared to the other three Border States, New Mexico, Arizona, and California, Texas is the state that has both the largest number of colonias and the largest colonia population (Federal Reserve Bank of Dallas, 2015). Specifically, Texas has approximately 2300 colonias with a total population of at least 450,000. The majority of the people living in colonias are Hispanic and about two thirds are US citizens (Texas Attorney General, 2011). Hidalgo, in 2007, had the largest number of colonias, which is considered one of the counties with the highest poverty rates in the United States (CHIPS, 2007). Colonias, for the most part, lack basic facilities such as water, sewage, electricity, paved streets, and sidewalks (Texas Attorney General, 2011). In 2014, there were 337 colonias with no access to drinkable water, wastewater disposal, and legal plats (Federal Reserve Bank of Dallas, 2015). Colonias have much higher occurrences of disease than any other part of the state. Some of the common diseases are hepatitis A, salmonellosis, dysentery, cholera, tuberculosis, and the presence of Hansen's disease or leprosy. In addition, there are cases of Dengue fever and Lyme disease carried by mosquitoes and ticks as a result of flooding and non-air conditioned homes. People in colonias also suffer from asthma and bronchitis due to the agricultural dust from sorghum, corn, cotton fields, and burned trash. The Operation Lone Star Program was established to provide free health care to colonias' residents who lack access to basic medical and dental treatment (Ramshaw, 2011).

\section{Research Questions}

The study answered the following research questions:

1. How do Tejas LEE scores differ in first grade bilingual classrooms of teachers implementing literacy centers and those who do not?

\section{LITERATURE REVIEW}

\section{Economically disadvantaged students}

The number of students who are economically disadvantaged or in poverty has increased dramatically in Texas public schools. According to the National Center for Children in Poverty, 45 percent of the seventy-two million children live in low-income families and 22 percent, equivalent to 16.1 million, live in poor families (Jiag, Ekono, \& Skinner, 2014). The poverty rate in 2014 for children under age 18 was 46.6 percent (U.S. Census Bureau, 2015). Berliner (2009), states that the problems of achievement among America's poor are much more likely to be located outside the school than in it. Berliner (2009) identified several problems that contribute to student achievement among America's poor: health care, food insecurity, pollution, family violence, and neighborhood. Other non-factors that have a negative effect on poor students' achievement, those that a school cannot control, include prenatal disadvantages, increased illness and injury, nutritional problems, exposure to pollutants, hazardous neighborhoods, struggle to survive, family violence, lack of adult attention, residential instability, and lack of educational activities and materials (Miami-Dade County Public Schools, 2009). 
The National School Lunch Program (NSLP) is a federally assisted meal program that provides nutritionally balanced, low-cost or free lunches to eligible students in public and non-profit schools and residential child care institutions. Children are eligible for free lunch if their family's income is at or below 130 percent of poverty level which is equivalent to $\$ 30,615$ for a family of four. On the other hand, children whose family income is between 130 percent and 185 percent of the poverty level are eligible for reduced-price lunches (National School Lunch Program, 2013). A school's socio economic status (SES) is usually measured by the percent of students eligible for reduced-price or free lunch programs (Sirin, 2005).

\section{Literacy acquisition}

Learning to read is an essential skill that children must possess in order to be successful in school and be prepared for the real world. According to Cunningham and Stanovich (1997), the ability to read at early years is a great predictor for performance in the later grades. The Reading Excellence Act (REA) (1999), specified as one of their objectives for every child to read by grade 3 , by improving reading instruction in high poverty, low performing schools by developing the skills of phoneme awareness, ability to decode unfamiliar words, read fluently, and develop vocabulary knowledge necessary for comprehension (Ramirez, 2000). In addition, the National Reading Panel (NRP) (2000) identified the five essential components, knows as "the big five", which include, phonemic awareness, phonics, fluency, vocabulary development, and comprehension. In order for children to acquire the literacy skills, students need to access opportunities for reading, writing, and talking in literacy-rich environments (Hoffman, J.V., et al, 2004). In a study by Pressley et al (1996), teachers suggest that strategies effective in promoting literacy included libraries, student work, chart stories and poems, lists of words, labels and signs, and learning centers.

\section{Literacy centers}

The joint statement of the International Reading Association (IRA) and the National Association for the Education of Young Children (NAEYC) (1998) advocates the use of literacy-enriched centers for all students for literacy development. In addition, Pressely, Rankin, and Yokoi's (1996) study showed that $85 \%$ of effective first grade primarylevel literacy teachers reported using centers. In Morrow's et al (1997) seminal work, the term literacy center is viewed as an area designed to provide space and materials for cooperative activities, composed of a library corner and a writing area. The idea of the literacy center has changed and is defined differently by proponents of this instructional approach. Diller (2003) coined the term "literacy work stations" to refer to an area where students work independently or with one another to explore and expand their literacy using available instructional materials that teachers had taught. Nations and Alonso (2001) described literacy centers as a place or activity that allows students to practice skills and strategies that have been modeled and taught in a balanced literacy program while the teacher conducts small group work.

Literature has shown that the implementation of literacy centers in the classroom has many benefits (Blakemore \& Ramirez, 1999; Diller, 2003; Fountas \& Pinnell, 1996; 
Holliman, 1996; Nations \& Alonso, 2001; Owocki, 2005; Swartz et al., 2003). According to Swartz et al., literacy centers allow students to independently practice reading, writing, listening, and speaking skills while completing the various activities. Nations and Alonso added the viewing component. Furthermore, literacy centers provide teachers the opportunity to work with individual students or small groups, which might be in the form of guided reading groups (Fountas and Pinnell, 1996; Blakemore \& Ramirez ,1999; Diller, 2003; Holliman, 1996; Nations \& Alonso, 2001; and Owocki, 2005). Literacy centers allow flexible grouping while students engage in small-group instruction. Nations and Alonso state, "Grouping students in heterogeneous groups gives your students a support system to complete their work in literacy centers and appreciate the strengths of center group members." (p. 32). Holliman (1996) and Fountas and Pinnell (1996) emphasize that literacy centers allow students to make choices. Nations and Alonso (2001) and Owocki (2005) stress that choice promotes engagement. Students have more ownership of their work and often exceed expectations. Nations and Alonso suggest the following list that teachers can follow to provide choice during literacy centers implementation: students select from a variety of activities within a center; students use a variety of materials to demonstrate understanding; students work independently or collaboratively; students choose ways to respond to a text; students decide where to work in the classroom. Implementation of literacy centers also allows the learner to be engaged through interaction (Blakemore \& Ramirez, 1999; Diller, 2003; Morrow, Mandel et al. 1997; Owocki, 2005). Morrow et al. (1997) revealed that students are engaged in three social behaviors when they are involved in group literacy activities: peer tutoring, peer collaboration, and peer conflict.

Literature emphasizes that the environment of the classroom is important to the success of literacy centers (Swartz et al., 2003). Owocki (2005) added that the physical environment in a classroom greatly influences children's learning, actions, and behaviors. Various literacy resources emphasize the importance of implementing routines and procedures (Owocki, 2005; Swartz et al., 2003). Fountas and Pinnell (1996) believed that every moment invested in teaching routines is time well spent, because it will save hours of instructional time later in the school year. At the beginning of the year, teachers need to introduce centers by going over the rules and procedures, what materials to be used, where they are stored, how to get them and arrange them, and how to put them away correctly. According to Nations and Alonso (2001), "good management is critical in order for literacy centers to run smoothly."

\section{Literacy centers related research}

Bates (2003) explored, through the naturalistic approach, the contextual elements surrounding literacy centers in a first grade classroom and how the elements influence children's literacy development. Participants included the teacher and 21 students as well as the researcher. The study yielded five contextual elements: teacher expectations, self-monitoring behaviors, materials and resources, social interactions, and physical design.

Stefanick's (2004) qualitative study utilized the constant-comparative or analytic induction to monitor children's perceptions of the process as well as their academic and 
social learning. Participants included nine kinder students with different achievement levels. Quantitative data was gathered, but a majority of the analysis was based on the qualitative data such as interviews, checklists, rubrics, reading and writing assessments, anecdotal notes, and portfolio samples. Findings showed that all children made pronounced gains in reading and writing skills, expanded their social and collaborative skills, and increased responsibility for their own learning.

Rodriguez's (2008) quasi-experimental study examined emergent literacy of bilingual students between or among types of instruction they received and level of administrative support during the implementation and monitoring of center learning in literacy-enriched environments. Participants consisted of 50 low socio economic status, bilingual, early childhood preschool children in five south Texas summer school sites. The study was conducted for four weeks during the summer school program. The control group consisted of 20 students while the experimental group had 30 students. The experimental group of students were involved in the seven super centers that consisted of a pretend and learn center, $\mathrm{ABC}$ center, creative center, construction center, math or science center, library or listening center, and writing center. At the end of the study, the experimental group had a significant difference in gains with emergent literacy CIRCLE scores posttests in eight areas. The eight areas included letter knowledge, vocabulary, listening skills, rhyme task 1 , rhyme task 2 , alliteration, words in a sentence and syllabication.

Maurer's (2010) qualitative study demonstrated how first grade children learned and practiced the English Language Arts standards while interacting in literacy centers. The population consisted of 19 White non-Hispanic children from a small, rural elementary school in an Ohio school district. Through a rotation schedule, the students completed literacy activities. Findings showed that children learned, practiced or used 47 of the 79 first grade indicators of literacy skills in the Ohio Academic Content Standards for English Language Arts. Peer dialogue mediated the following English Language Arts standards through the use of literacy centers: decoding skills, vocabulary development, and comprehension skills.

O'Donnell and Hitpas' (2010) qualitative action research studied the use of learning centers in a kindergarten classroom. Data collection involved data triangulation through the use of interviews, work samples, anecdotal records, checklists, videotapes, and performance task documents, for six students from the kindergarten classroom. All students in the classroom were provided with a choice of 14 literacy centers that contained multiple of activities from an extensive review of literature. Results demonstrated that at-risk students made progress in achievement, accountability, and motivation.

Stout (2009) conducted an action research project to investigate the effectiveness of literacy centers implementation. The research was conducted for six weeks in a first grade classroom located in a large urban district in the American Southwest. The Pre-K through $5^{\text {th }}$ grade school is designated as a Title 1 school, with $92 \%$ of students being economically disadvantaged. Eighty-six percent of the student population is Hispanic, twelve percent are African American, and two percent are White. Data collection 
consisted of anecdotal records, work samples and a teacher-research journal. At the end of the study, the six selected students increased an average of four reading levels on the Developmental Reading Assessment (DRA). Data also showed that students who made the smallest improvements were the students most frequently off-task during center time compared to students who made the most improvement.

\section{METHOD}

The researcher utilized a quasi-experimental research design, where experimental and comparison groups were established but there was no random assignment of subjects. The study utilized a pretest and posttest design in which both groups were tested at two points in time, resulting in a two by two repeated measures design (Creswell, 2002). The independent variable was the implementation of literacy centers in first grade bilingual classrooms. The outcome measures were the first grade students' Tejas LEE scores, which consisted of (1) story 1 accuracy, (2) story 2 accuracy, (3) story 1 fluency, (4) story 2 fluency, (5) story 1 explicit questions, (6) story 1 implicit questions, (7) story 2 explicit questions, and (8) story 2 implicit questions.

\section{Sample}

A convenience sample was used to select the participants for the experimental and comparison groups. According to Johnson and Christensen (2008), the use of convenience sampling allows the researcher to recruit individuals that are willing to participate in the research study. However, it is a type of non-probability sampling; thus, external validity is limited to the study's participants. The participants were Hispanic first grade bilingual students from two south Texas elementary schools from the same district located in the Rio Grande Valley. All were from colonias.

At the beginning of the study, the sample consisted of 112 first grade Hispanic bilingual students. As expected, there was attrition. The 104 first grade bilingual students (59 and 45 in the experimental and comparison groups, respectively) who had both the pretest and post-test data were included in analysis and interpretation of the quantitative data. The distribution of the sample means will be approximately normal distributed since the sample consisted of more than 30 students (LaMorte, 2016). The experimental classrooms were selected due to their voluntary agreement to participate in the study. The participating elementary schools had comparable demographics based percentage of Hispanic, economically disadvantaged, limited English and at-risk. School had the following similar demographics based on Texas Education Agency 2011-2012: Hispanic 100\%; economically disadvantaged $97.4 \%$; limited English $83.6 \%$; and at-risk $89.4 \%$. School B also had 100\% Hispanic; 97.9\% economically disadvantaged; 83.8 limited English; and $89.6 \%$ at-risk.

\section{Intervention}

In this study, the students in the experimental group received literacy acquisition through the implementation of literacy centers along with the state-adopted reading program, Tesoros, during the language arts block. The intervention lasted for 11 weeks, three days per week, Tuesday, Wednesday, and Thursday. Mondays were dedicated for 
the teacher to teach all the weekly language arts objectives and review the literacy center expectations and activities. On Fridays, teachers administered all required weekly assessments. The researcher provided the teachers in the experimental group with several workshops related to the implementation of literacy centers including types of activities that targeted the skills addressed in Tejas LEE and the objectives from the reading adoption. Additionally, all four teachers participated in several make-and-take sessions that allowed them to prepare activities for the various literacy centers.

The classrooms in the experimental group included literacy centers that targeted the reading concepts addressed in the first grade Tejas LEE and the required first grade TEKS (Texas Essential Knowledge and Skills). Teachers in the experimental group conducted small-group instruction based on the Tejas LEE BOY criteria while students worked in literacy centers. The classrooms in the experimental group implemented the literacy centers explained below which were listed in the Literacy Student Planning Form, referred to as LSPF and displayed on the literacy center management board. The LSPF was used to color-in the literacy centers that were visited on a daily basis. Students received a new form every week and completed forms were placed in their literacy center folders. Teachers used the literacy center management board for students to place their selected bug, butterfly or hummingbird, in the literacy center that they were selecting for that time. Once the student completed the required literacy center activity, the bug was moved to another literacy center.

The following literacy centers were implemented during the study: (1). Spelling Center: In the spelling center, the teacher placed different games or activities that allowed the student to practice weekly spelling words; (2). Writing Center: In the writing center, students practiced the weekly writing objectives by completing foldable or different writing activities, such as pop-up cards, or dioramas; (3). Library Center: In this center, students had the opportunity to read a self-selected book independently or with a reading buddy. After reading a book, students completed a reading log with information about the book as well as a graphic organizer; (4). Computer Center: In the computer center, students played educational games or listened to the story of the week from the reading adoption website, www.connectEd; (5). Art Center: In this center, students completed an art project from the adopted art book using different types of materials such as paint, and tissue paper; (6). Poetry Center: In the poetry center, students practiced reading a Spanish nursery rhyme, such as "Tortillitas" (Ada \& Campoy, 2003). They also worked in a poetry notebook by pasting in the nursery rhyme and illustrating it. Additionally, they sorted the poem's words or sentences on the pocket chart or on the floor; (7). Pocket Chart Center: In the pocket chart center, students manipulated sentence strips or picture cards with words to practice weekly reading skills such as hearing beginning sounds or noticing different types of punctuation in sentences; (8). Listening Center: the listening center contained stories on audio from the Capstone library website. Students completed the listening log after the story; (9). Word Study Center: In the word study center, students engaged in hands-on activities or games to practice reading words with the phonics element of the week or high frequency words; (10). Small-Group Instruction Center: In this center, the teacher met with several students based on their needs to provide differentiated instruction such as blending, segmenting, and reading with 
fluency. Teachers used this time to listen to the students read orally from the reading adoption's level readers. The students in the comparison group received language arts instruction through the implementation of the state-adopted reading program, Tesoros, just as the experimental group did but without the implementation of the literacy centers.

\section{Data Collection}

Educators across the state of Texas are required to administer the Tejas LEE to students in order to assess their strengths and weaknesses in reading ability. Students' test scores from the Tejas LEE were obtained at the beginning of the school year to establish a baseline for the study. The researcher collected Tejas LEE scores from students in the comparison and experimental groups to answer the research question: "How do Tejas LEE scores differ in first grade bilingual classrooms of teachers implementing literacy centers and those who do not?" Data collection occurred during the study's 11-week duration. At the beginning of the school year, teachers administered the Tejas LEE. After the administration of the assessment, the researcher collected class reports that showed the areas in which students fell into either developed or needs intervention categories. A developed status meant that the child had acquired the skills from that section. If the student fell into the needs intervention category, it meant that the teacher had to provide future lessons in that skill. At the end of the study in January 2014, Tejas LEE MOY test scores were collected from both groups.

\section{Instrumentation}

To answer the study's research question, Tejas LEE (El inventario de lectura en Espanol de Tejas) BOY and MOY scores were used. The Tejas LEE is a Spanish reading instrument first and administered to students receiving instruction in Spanish in grades kindergarten through second grade to determine areas necessary to the development of Spanish reading and reading comprehension. Students are assigned a reading level from three different performance levels of scoring, namely, desarollado (developed), when the student has mastered the skill; nivel esperado (expected performance), assigned to students who have not yet mastered the skill but are well on their way to mastery; and nivel de intervencion (needs intervention), when the student is performing in the lowest $25 \%$ of the population on the skill and intervention is needed. In first grade, teachers administer Tejas LEE to the students three times per year (beginning, middle, and end of year). Five reading concepts are addressed in the first grade Tejas LEE; however only three areas were used for the data analysis: graphophonemic knowledge, phonological awareness, reading accuracy, reading fluency, and reading comprehension. In the following section, each reading concept addressed in the inventory is described as well as the activity used to test it on the Tejas LEE (TEA \& University of Texas System, 2010).

\section{Reading Accuracy "exactitud de lectura"}

Reading accuracy entails the ability to automatically decode and identify words. Words read incorrectly are tracked as the student reads a story orally. The types of errors that are counted are mispronunciations, substitutions, and omissions. Insertions, selfcorrections, or repetitions are not counted as errors. The students are not allowed to 
continue reading if three errors are made in the first sentence. The students are assigned a level for each story depending on the number of errors for each story. The levels consist of independent, instructional and frustrational.

Reading Fluency "fluidez de lectura"

Reading fluency occurs when the student has the ability to read fluently with expression and appropriate intonation and phrasing. Fluency is measured by timing the student while reading the story in order to calculate the words correct per minute "palabras leidas correctamente por minuto," known as PLCPM.

\section{Reading Comprehension "comprensión de lectura"}

Reading comprehension refers to the ability to extract meaning from written text both explicitly (stated directly in the text) and implicitly (inferred from the text). Reading comprehension is assessed by having the student answer one implicit questions and four explicit comprehension questions for story 1 and story 2 at the beginning of the year (BOY) and 2 implicit and 6 explicit comprehension questions at the middle of the year administration (MOY).

\section{Data Analysis}

The researcher performed descriptive and inferential statistics, using the Statistical Package for the Social Sciences (SPSS). Descriptive statistics were used to summarize and organize the data, which consisted of frequency and percentage distribution tables, measures of central tendency, and measures of variability. A series of t-test for independent samples (Stevens, 2009) was performed to compare the experimental and comparison groups on the basis of pretest measures of reading fluency story 1 , reading fluency story 2 , explicit and implicit comprehension questions story 1 , and explicit and implicit comprehension questions story to establish pre-experimental equivalence. A series of 2 by 2 repeated measure analysis of variance (RMANOVA) was performed to examine and main and interaction effects of the intervention and time on the abovementioned measures. Mean difference effect sizes (Cohen, 1988) were computed to examine the practical significance of the findings and were characterized as $.2=$ small effect, $.5=$ medium effect, and $.8=$ large effect. A series of chi-square test of independence (Field, 2013) was performed to examine the null hypotheses that reading accuracy for story 1 and story 2, coded as independent, instructional, or frustrational and membership in the intervention or comparison groups were independent of each other.

\section{FINDINGS}

The Tejas Lee scores were: (1) story 1 accuracy, (2) story 2 accuracy, (3) story 1 fluency, (4) story 2 fluency, (5) story 1 explicit questions, (6) story 1 implicit questions, (7) story 2 explicit questions, and (8) story 2 implicit questions.

\section{Analysis of Tejas LEE Scores}

The study's research question was "How do Tejas LEE scores differ in first grade bilingual classrooms of teachers implementing literacy centers and those who do not?" 
There were 104 (experimental group: 28 male and 31 females; comparison group: 21 male and 24 female) Hispanic first grade bilingual students who provided the pretest and posttest data. The experimental and comparison groups were compared on the basis of the pretest measures of six of the outcome measures, which were continuous in nature. None of the differences were statistically significant; thus, pre-experimental equivalence on the basis of these measures was assumed. Results are summarized in Table 1.

Table 1

Comparison of pretest differences on tejas LEE measures

\begin{tabular}{|c|c|c|c|c|c|c|}
\hline & \multicolumn{2}{|c|}{$\begin{array}{l}\text { Experimental Group } \\
n=59\end{array}$} & \multicolumn{4}{|c|}{$\begin{array}{c}\text { Comparison Group } \\
\mathrm{n}=45\end{array}$} \\
\hline & M & SD & M & SD & $\mathrm{t}$ & $\mathrm{p}$ \\
\hline Reading Fluency Story 1 & 21.85 & 24.98 & 23.02 & 25.24 & .24 & .81 \\
\hline Reading Fluency Story 2 & 20.83 & 23.43 & 19.64 & 22.50 & .26 & .80 \\
\hline Explicit Comprehension & .54 & .48 & .47 & .46 & .76 & .45 \\
\hline \multicolumn{7}{|l|}{ Questions Story 1} \\
\hline Implicit Comprehension & .49 & .50 & .40 & .50 & .92 & .36 \\
\hline \multicolumn{7}{|l|}{ Questions Story 1} \\
\hline Explicit Comprehension & .46 & .43 & .34 & .37 & 1.53 & .13 \\
\hline \multicolumn{7}{|l|}{ Questions Story 2} \\
\hline $\begin{array}{l}\text { Implicit Comprehension } \\
\text { Questions Story } 2\end{array}$ & .56 & .50 & .42 & .50 & 1.38 & .17 \\
\hline
\end{tabular}

The largest $n$ (59 in the experimental group) divided by the smallest $n$ (45, in the comparison group) was less than 1.50 (1.31); thus, the two sample sizes were assumed to be approximately equal and robust with respect to the assumption of equality of covariance matrices (Stevens, 2009). A series of 2 by 2 repeated measures analysis of variance was performed to examine the main and interaction effects of intervention and time on various outcome measures.

Table 2

Means and standard deviations for tejas LEE posttests for all measures

\begin{tabular}{|c|c|c|c|c|}
\hline & \multicolumn{2}{|c|}{$\begin{array}{c}\text { Experimental Group } \\
\mathrm{n}=59\end{array}$} & \multicolumn{2}{|c|}{$\begin{array}{c}\text { Comparison Group } \\
\mathrm{n}=45\end{array}$} \\
\hline & M & SD & M & SD \\
\hline Reading Fluency Story 1 & 42.10 & 28.44 & 45.02 & 19.60 \\
\hline Reading Fluency Story 2 & 41.85 & 27.91 & 43.62 & 23.48 \\
\hline \multicolumn{5}{|l|}{ Explicit Comprehension } \\
\hline Questions Story 1 & .79 & .36 & .81 & .30 \\
\hline \multicolumn{5}{|l|}{ Implicit Comprehension } \\
\hline Questions Story 1 & .64 & .37 & .58 & .32 \\
\hline \multicolumn{5}{|l|}{ Explicit Comprehension } \\
\hline Questions Story 2 & .82 & .34 & .79 & .34 \\
\hline $\begin{array}{l}\text { Implicit Comprehension } \\
\text { Questions Story } 2\end{array}$ & .58 & .41 & .54 & .41 \\
\hline
\end{tabular}


Repeated measures analysis of data for Reading Fluency Story, showed that the time effect was statistically significant, $F(1,102)=168.44, p<.01$. The intervention effect, $F(1,102)=.19, p=.66$, and the time by intervention interaction effect, $F(1,102)=.29$, $p=.59$, were not statistically significant. Repeated measures analysis of data for Reading Fluency Story 2, showed that the time effect was statistically significant, $F$ $(1,102)=164.71, p<.01$. The intervention effect, $F(1,102)=.01, p=.95$, and the time by intervention interaction effect, $F(1,102)=.71, p=.40$, were not statistically significant. Repeated measures analysis of data for Explicit Comprehension Questions Story 1 , showed that the time effect was statistically significant, $F(1,102)=51.06, \mathrm{p}<$ .01 . The intervention effect, $F(1,102)=.12, p=.73$, and the time by intervention interaction effect, $\mathrm{F}(1,102)=1.29, p=.26$, were not statistically significant. Repeated measures analysis of data for Implicit Comprehension Questions Story 1, showed that the time effect was statistically significant, $F(1,102)=10.54, p<.01$. The intervention effect, $F(1,102)=1.16, p=.29$, and the time by intervention interaction effect, $F$ $(1,102)=.12, p=.74$, were not statistically significant. Repeated measures analysis of data for Explicit Comprehension Questions for Story 2, showed that the time effect was statistically significant, $F(1,102)=117.44, \mathrm{p}<.01$. The intervention effect, $F(1,102)$ $=1.54, p=.22$, and the time by intervention interaction effect, $F(1,102)=1.35, p=.25$, were not statistically significant. Repeated measures analysis of data for Implicit Comprehension Questions for Story 2, showed that the intervention effect, $F(1,102)=$ $1.32, p=.25$, the time by intervention interaction effect, $F(1,102)=1.07, p=.30$, and the time effect, $\mathrm{F}(1,102)=2.49, p=.12$, were not statistically significant.

\section{Analysis of Effect Sizes}

The time effect on story 1 fluency, story 2 fluency, story 1 explicit questions, story 1 implicit questions, story 2 explicit questions, and story 2 implicit questions was statistically significant. To better understand the results, pretest to posttest mean difference effect sizes were computed and characterized as $.20=$ small effect, $.50=$ medium effect, and $.80=$ large effect. The effect sizes were computed for all subjects, subjects in the experimental group, and subjects in the comparison groups. As can be seen in Table 3, the largest pretest to posttest improvements belonged to reading fluency scores, while implicit comprehension scores showed the smallest improvement. Results are summarized in Table 3. 
Table 3

Pretest to posttest measures difference effect sizes*

\begin{tabular}{lccc}
\hline & ALL & $\begin{array}{c}\text { Experimental } \\
\text { Group }\end{array}$ & $\begin{array}{c}\text { Comparison } \\
\text { Group }\end{array}$ \\
\hline $\begin{array}{l}\text { Explicit Comprehension } \\
\text { Questions Story 1 }\end{array}$ & .69 & .65 & .74 \\
\hline Implicit Comprehension & .32 & & .33 \\
\hline Questions Story 1 & & & 1.19 \\
\hline Explicit Comprehension & 1.06 & .96 & .26 \\
\hline Questions Story 2 & & & \\
\hline Implicit Comprehension & .14 & & 1.31 \\
\hline Questions Story 2 & & 1.25 & 1.17 \\
\hline Reading Fluency Story 1 & 1.28 & 1.38 & \\
Reading Fluency Story 2 & 1.26 & & \\
\hline
\end{tabular}

*Mean Difference Effect Size: $.20=$ Small, $.50=$ Medium, $.80=$ Large

\section{Analysis of Accuracy Data}

A series of chi-square test of independence was performed to test the null hypotheses that participation in the literacy centers and the pretest and posttest evaluations of reading accuracy, categorized as independent, instructional, or frustrational, were independent of each other.

Table 4

Frequency Measures for Pretest and Postest Story 1 Accuracy, $\mathrm{n}=104$

\begin{tabular}{crcrr}
\hline & & Experimental Group & \multicolumn{2}{c}{ Comparison Group } \\
\hline Levels & $\mathrm{F}$ & $\%$ & $\mathrm{~F}$ & $\%$ \\
Independent & & & 18 & 40.00 \\
Pretest & 29 & 49.20 & 36 & 80.00 \\
Posttest & 48 & 81.40 & 6 & 13.30 \\
Instructional & & & 6 & 13.30 \\
Pretest & 6 & 10.20 & & \\
Posttest & 2 & 3.40 & 21 & 46.70 \\
Frustrational & & & 3 & 6.70 \\
\hline Pretest & 24 & 40.70 & & \\
Posttest & 9 & 15.30 & & \\
\hline
\end{tabular}

According to Table 4, on the basis of reading accuracy for story 1 at pretest, the null was not rejected, $X^{2}(2, \mathrm{n}=104)=.91, p=.64$, and it was concluded that the two variables were independent of each other. The independent level was observed the most, followed by frustrational, and instructional. On the basis of reading accuracy for story 1 at posttest, the null was not rejected, $X^{2}(2, n=104)=4.92, p=.09$, and it was concluded that the two variables were independent of each other. An examination of the count data, showed that the independent level was observed the most, followed by frustrational, and instructional. 
Table 5

Frequency measures for pretest and postest story 2 accuracy, $n=104$

\begin{tabular}{ccccc}
\hline Levels & F & $\begin{array}{c}\text { Experimental Group } \\
\%\end{array}$ & \multicolumn{2}{c}{ Comparison Group } \\
$\%$
\end{tabular}

According to Table 5, on the basis of reading accuracy for story 2 at pretest, the null was not rejected, $X^{2}(2, \mathrm{n}=104)=1.55, p=.46$, and it was concluded that the two variables were independent of each other. The independent level was observed the most, followed by frustrational, and instructional. On the basis of reading accuracy for story 2 at posttest, the null was not rejected, $X^{2}(2, \mathrm{n}=104)=.26, p=.88$, and it was concluded that the two variables were independent of each other. As can be seen in Table 21, the independent level was observed the most, followed by frustrational, and instructional.

\section{DISCUSSION}

The results of this quasi-experimental study do not support the notion that literacy centers in first grade bilingual classrooms can result in significant gains in students' literacy development. Even though the results were not statistically significant for several of the Tejas LEE test components, students in the experimental and the comparison groups made gains in their literacy development as can be seen on the Tejas LEE scores. Students improved the areas of fluency, accuracy and comprehension by practicing reading, writing, listening and speaking through the use of literacy centers , as highlighted by Swartz, et al (2003). The difference between the mean scores could be due to chance or to the sample size rather than the intervention (McClusky and Lalkhen, 2007). Previous studies have demonstrated reading improvement when teachers implement literacy centers (Stefanick. 2004; O’Donnell, \& Hitpas, 2010; Stout, 2009), including with bilingual students (Rodriguez, 2008).

Effect sizes within the experimental group literacy tasks indicate that beyond results not being statistically significant, the differences between groups on four measures were medium to large, and thus educationally relevant. This data, thus, proves that the implementation of literacy centers were effective with bilingual first-grade students. The experimental group scored more than $80 \%$ than the control group in the following areas: Explicit Comprehension Questions for Story 2 of .96, the value of 82\%; Reading Fluency Story 1 had an effect size of 1.25 , the value of $88 \%$; and Reading Fluency Story 2 with the effect size of 1.38 , the value of $88 \%$, as well. Furthermore, the experimental group scored $73 \%$ higher than the control group in Explicit Comprehension Questions 
Story 1 (Coe, 2002). In addition, students from both groups might have received good instruction since the same reading adoption was being used.

Literacy centers implementation involves more work, and demands more time than other methods of teaching. During the study, teachers had to prepare on a weekly basis the recommended literacy activities aligned with the first grade TEKS based on the First Grade Literacy Planning Forms. In addition, teachers had to plan the intervention activities that were used during small-group instruction based on students' reading abilities.

Furthermore, the availability of the assessment instrument to the teachers from both groups, could have affected the Tejas LEE scores. Teachers have the access to the Tejas LEE BOY and MOY assessment throughout the year. Therefore, an assessment instrument that is not accessible to teachers might have been a better selection, making sure that teachers do not overuse the assessment content.

\section{IMPLICATIONS}

Although this was a small study, data from the descriptive and inferential statistical analyses can be used to provide insightful information in the areas of classroom instruction and pre-service teacher preparation programs. The major contribution of the present study is that it provides data on the effects of literacy centers to develop literacy development in first grade bilingual students. The results did show gains in student achievement. The study has implications for current educators and future educators teaches who aim to enhance implementation of literacy centers to improve students' literacy development.

First-grade teachers may consider implementing literacy centers since students responded positively to this instructional approach that incorporated hands-on activities aligned with TEKS and Tejas LEE tasks. Such method appears to increase the following Tejas LEE components: fluency, comprehension and spelling. This method might increase the number of students at the independent and instructional level and reduce the number of students at the frustrational level. Literacy centers can be a valuable instructional approach for primary grade level practitioners to develop student's literacy development. Administration need to provide the appropriate professional development along with time to prepare the activities for the literacy centers.

Teacher preparation programs may restructure their curriculum to include content on literacy centers implementation in their reading courses. Currently, reading courses include content on learning centers but not in literacy centers. Reading courses should provide students the opportunity to read research articles on literacy centers and how to align them with the literacy standards. These programs must ensure that pre-service teachers learn about developing student's literacy development through the implementation of literacy centers. 


\section{LIMITATIONS OF THE STUDY}

Several limitations were present during the study. The first limitation to the study was the number of schools involved in this "real-life" setting investigation. There was only one school selected due to the fact that the researcher had access to the site. The number of subjects in the study is another limitation that needs to be addressed. All teachers in first-grade bilingual classrooms were invited to participate in the study; however, some first-grade classrooms were unable to participate. Furthermore, the duration of the study is another limitation that needs to be mentioned. However, the findings from this study might be a starting point by educators, especially in the lower grades, on how to develop students' literacy development through literacy centers implementation.

\section{CONCLUSION}

Based on the quantitative results from the study, it was concluded that there was no statistically significant difference between those students who participated in literacy centers and those who did not on the basis of academic achievement in Tejas LEE scores. Therefore, the null hypothesis was not rejected. The implementation of literacy centers helped students to become readers and will eventually be successful in later grades, as proposed by Cunningham and Stanovich (1997). As a result of this intervention, the number of students that were non-readers decreased and more students became independent readers. Literacy centers allows the students the opportunity to work in a literacy-rich environment to acquire the required skills to become independent readers (Pressely, et al., 1996). Eventually, this literacy improvement will increase the number of students graduate from high school and prevent them from being incarcerated (Kenneady, 2004).

\section{SUGGESTIONS FOR FUTURE RESEARCH}

The recommendations for further research that emerged from this study are listed below:

1. Conduct a replication of this literacy centers implementation study with longer treatment time (one year) or in a variety of grade levels.

2. Conduct a study that describes the attitudes and perceptions of teachers using literacy centers to develop students' literacy development.

3. Conduct a study that describes the effects of literacy centers on students' attitudes and academic achievement.

4. Use an enlarged sample of multiple schools to provide a broader sense of reading achievement and literacy centers.

5. Conduct a longitudinal literacy centers study that follows the progress of participants involved in the study, as they move to higher grades.

6. Investigate the effectiveness of small-group instruction while students work in literacy centers. 


\section{REFERENCES}

Ada, A. F. \& Campoy, F. I. (2003). !Pio Peep! Traditional Spanish nursery rhymes.

New York: Harper Collins.

Bates, C. C. (2003). Literacy centers in a first-grade classroom: The contextual elements and their influence on literacy learning (Doctoral dissertation). Retrieved from ProQuest Dissertations and Theses database. (UMI No. 3110122)

Berliner, D.C. (2009). Are teachers responsible for low achievement by poor students? Kappa Delta Pi Record, 18-21. Retrieved from file:///C:/Users/user/Downloads/Berliner.pdf

Blakemore, C. J., \& Ramirez, B. W. (1999). Literacy centers for the primary classroom. Parsippany, NJ: Dominie Press.

CHIPS (Colonias, Heath, Infrastructure, and Platting Status). (2007). Retrieved from http://borderhealth.cr.usgs.gov/datalayers_nojava.html

Coe, R. (2002). It's the effect size, stupid: What effect size is and why is it important. Retrieved

from https://pdfs.semanticscholar.org/c5ac/87df5d6e0e6b6de2f745284835c2a368b0f7.pdf? $\mathrm{ga}=2.161079870 .204109375 .1585970548-981932215.1585970548$

Field, A. (2013). Discovering statistics: Using IBM SPSS statistics, $\left(4^{\text {th }}\right.$ ed.). Thousand Oaks, California: SAGE Publications.

Fountas, I. C., \& Pinnell, G. S. (1996). Guided reading: Good first teaching for all children. Portsmouth: Heinemann.

Fromberg, D. P. (2002). Play and meaning in early childhood education. Boston, Massachusetts: Allyn \& Bacon.

Hernandez, D.J. (2012). Double Jeopardy: How third-grade reading skills and poverty influence high school graduation. Baltimore, Maryland. Retrieved from http://gradelevelreading.net/wp-content/uploads/2012/01/Double-Jeopardy-Report030812-for-web1.pdf

Hoffman, J.V., Sailors, M., Duffy, G.R., \& Beretvas, S.N. (2004). The effective elementary classroom literacy environment: Examining the validity of the TEX-IN3 observation system. Journal of Literacy Research, 36(3) 303-334.

Holliman, L. (1996). The complete guide to classroom centers: Hundreds of ideas that really work! Cypress, CA: Creative Teaching Press.

International Reading Association (IRA) and the National Association for the Education of Young Children (NAEYC). (1998). Learning to read and write: Developmentally appropriate practices for young children. The Reading Teacher, 52, 193-216. 
Jiang, Y., Ekono, M., \& Skinner, C. (2014). Basic facts about low-income children. Retrieved from file:///C:/Users/user/Downloads/Basic_Facts_Children_12_through_17_2012.pdf

Johnson, B., \& Christensen, L. (2008). Educational research: Quantitative, qualitative, and mixed approaches ( $3^{\text {rd }}$ ed.). Thousand Oaks, California:Sage Publications.

Kenneady, L.M. (2004). Good for nothing in grade retention. Intercultural Development Research Association. Retrieved from http://files.eric.ed.gov/fulltext/ED484914.pdf

LaMorte, W.W. (2016). The role of probability: Central limit theorem. Retrieved from http://sphweb.bumc.bu.edu/otlt/MPHModules/BS/BS704_Probability/BS704_Probabilit y12.html

Maurer, C. (2010). Meeting academic standards through peer dialogue at literacy centers. Language Arts, 87(5), 353-362.

McCluskey, A., \& Lalkhen, A. G. (2007). Statistics IV: Interpreting the results of statistical tests, CEACCP, 7(6), 208-212. Retrieved from http://ceaccp.oxfordjournals.org/content/7/6/208.full

Miami-Dade County Public Schools (2009). The effect of poverty on student achievement. Retrieved from http://files.eric.ed.gov/fulltext/ED544709.pdf

Morrow, L. M. et al. (1997). Differences between Social and Literacy Behaviors of First, Second, and Third Graders in Social Cooperative Literacy Settings. Retrieved from http://files.eric.ed.gov/fulltext/ED406667.pdf

Miller, E., \& Almon, J. (2009). Crisis in the kindergarten: Why children need to play in school. Retrieved from Alliance for Childhood: http://www.allianceforchildhood.org/sites/allianceforchildhood.org/files/file/kindergarte n_report.pdf

National Center for Education Statistics. (2015). The nation's report card: Reading 2015. Washington, DC: Institute of Education Sciences. Retrieved from http://www.nationsreportcard.gov/reading_math_2015/\#reading/groups?grade=4

National School Lunch Program. (2013). Retrieved from http://www.fns.usda.gov/sites/default/files/NSLPFactSheet.pdf

National Institute of Child Health and Human Development (2000). National Reading Panel: Teaching children to read. Retrieved from https://www.nichd.nih.gov/sites/default/files/publications/pubs/nrp/Documents/report.pd f

Nations, S., \& Alonso, M. (2001). Primary literacy centers: Making reading and writing STICK. Gainesville, FL: Maupin House.

O’Donnell, B. D., \& Hitpas, R. (2010). Two teachers learn from their students: Examining teaching, learning, and the use of learning centers. Networks, 12(2), 1-8. Retrieved from file://C:/Users/user/Downloads/254-1580-1-PB.pdf 
Owocki, G. (2005). Time for literacy centers: How to organize and differentiate instruction. Portsmouth, NH: Heinemann.

Pressley, M., Rankin, J., \& Yokoi, L. (1996). A survey of instructional practices of primary teachers nominated as effective in promoting literacy. The Elementary School Journal, 96(4), 363-384.

Ramirez, J.D. Bilingualism and literacy: Problem or opportunity? A synthesis of reading research of bilingual students. U.S. Department of Education: Washington, DC.

Ramshaw, E. (2011, July 11). Major health problems linked to poverty. The New York Times. Retrieved from http://www.nytimes.com

Rodriguez, I. C. (2008). An examination of center learning on emergent literacy in bilingual childhood classrooms. (Doctoral dissertation). Retrieved from ProQuest Dissertations and Theses database. (UMI No. 744447821)

Saracho, O.N., \& Spodek, B. (2006). Young children's literacy-related play. Early Child Development and Care, 176(7), 707-721.

Singer, D. G., Golinkuff, R. M., \& Hirsch-Pasek, K. (Eds.). (2006). Play=learning. New York: Oxford University Press.

Sirin, S. R. (2005). Socioeconomic status and academic achievement: A meta-analytic review of research. Review of Educational Research, 75(3), 417-453.

Stefanick, P. (2004). Kindergarten literacy centers: Students' perceptions of academic and social learning. (Doctoral dissertation). Retrieved from ProQuest Dissertations and Theses database. (UMI No. 3156732)

Stevens, J. P. (2009). Applied multivariate statistics for the social sciences $\left(5^{\text {th }}\right.$ ed.). New York: Routledge.

Stout, R. (2009). Putting literacy centers to work: A novice teacher utilizes literacy centers to improve reading instruction. Networks, 11(1), 1-6. Retrieved from file://C:/Users/user/Downloads/181-815-1-PB.pdf

Swartz, S. L., Shook, R. E., Klein, A. F., Moon, C., Bunnell, K., Belt, M., \& Huntley, C. (2003). Guided reading \& Literacy centers. Carlsbad, CA: Dominie Press.

Sum, A., Khatiwada, I., McLaughlin, J., \& Palma, S. (2009). The consequences of dropping out of high school. Boston, Massachusetts. Retrieved from http://www.northeastern.edu/clms/wp-

content/uploads/The_Consequences_of_Dropping_Out_of_High_School.pdf

Texas Attorney General. (2011). Texas colonias: A thumbnail sketch of conditions, issues, challenges and opportunities. Retrieved from http://www.sos.state.tx.us/border/colonias/faqs.shtml

Texas Education Agency. (2015). Grade-level retention in Texas public schools, 2013 14 (Document No. GE16 601 08). Austin TX: Author. 
Texas Education Agency. (2016). Student testing and accountability. Retrieved from http://tea.texas.gov/student.assessment/ell/telpas/

Tyre, P. (2006, September 10). The new first grade: Too much too soon? Newsweek. Retrieved from http://www.newsweek.com

US Census Bureau (2015). People in poverty by selected characteristics: 2013 and 2014.

Retrieved

from

http://www.census.gov/hhes/www/poverty/data/incpovhlth/2014/table3.pdf 